\title{
Electrocardiography as a Diagnostic Method for Chagas Disease in Patients and Experimental Models
}

\author{
Patricia Paglini-Oliva, Silvina M. Lo Presti and H. Walter Rivarola \\ Cátedra de Física Biomédica, Facultad de Ciencias Médicas, \\ Universidad Nacional de Córdoba \\ Argentina
}

\section{Introduction}

The electrocardiogram (ECG) is a simple test that detects and records the electrical activity of the heart that is externally recorded by skin electrodes. It is a noninvasive recording produced by an electrocardiographic device. The etymology of the word is derived from the Greek electro, because it is related to electrical activity, cardio, Greek for heart, and graph, a Greek root meaning "to write".It is used to detect and locate the source of heart problems.

The electric activity of the heart is produced by the depolarization and repolarization of the cardiac cells and in each heart beat a healthy heart will have an orderly progression of a wave of depolarization that is triggered by the cells in the sinoatrial node, spreads out through the atrium, passes through intrinsic conduction pathways and then spreads all over the ventricles. This electric activity will be responsible of an ordered contraction first of the atria and then of the ventricles.

The recording of an electrocardiogram is using usually more than 2 electrodes that can be combined into a number of pairs ( Left arm (LA), right arm (RA) and left leg (LL) electrodes form the pairs: $L A+R A, L A+L L, R A+L L)$. The output from each pair is known as a lead. Each lead registers the electric activity of the heart from a different angle.

The electrocardiogram is one of the best and easy way to measure and diagnose abnormal rhythms of the heart, particularly abnormal rhythms caused by damage to the conductive tissue that carries electrical signals, or abnormal rhythms caused by electrolyte imbalances. In a myocardial infarction, the ECG can identify if the heart muscle has been damaged in specific areas, though not all areas of the heart are covered. The ECG cannot reliably measure the pumping ability of the heart, for which ultrasound-based (echocardiography) or nuclear medicine tests are used.

Heart failure is a highly prevalent chronic disease that results in varying degrees of functional alteration. One of the most important determinants of congestive heart failure and sudden death in Latin America is Chagas disease provoked by the infection with the intracellular protozoan Trypanosoma cruzi. It affects approximately 20 million people (WHO 2007; Moncayo and Silveira 2009) and represents a serious public health problem in Central and South America ( Biolo et al 2010) 
Among the different aetiologies, chagasic cardiopathy appears to carry the worst prognosis (Pereyra et al 2008) and has become the most frequent cause of heart failure and sudden death, as well as the most common cause of cardioembolic stroke in Latin America.

In Chagas-endemic areas, the main mode of transmission is through an insect vector called a triatomine bug that becomes infected with $T$. cruzi by feeding on the blood of an infected person or animal. During the day, triatomines hide in crevices in the walls and roofs. The bugs appears at night and bite the sleeping people to ingest blood, after that they defecate and by scratching the host favors the T. cruzi (trypomastigotes) entrance that are in the bug feces . Once inside the host, the trypomastigotes invade cells (amastigotes) The amastigotes multiply and differentiate again into trypomastigotes, which are then released into the bloodstream. This cycle is repeated in each newly infected cell and every time a triatomine bites an infected people.

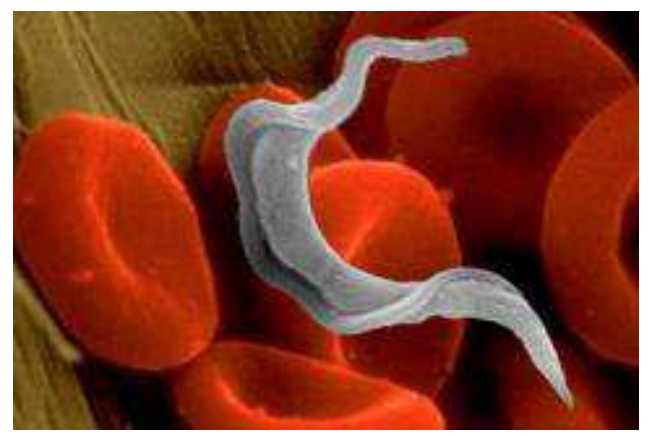

Fig. 1. Trypomastigote of Trypanosoma cruzi between red blood cells.

T. cruzi can also be transmitted through blood transfusions; this form is not common because in endemic areas the blood control is exhaustive and in EEUU and Europe are now paying attention to this matter. Other modes of transmission include organ transplantation, accidental laboratory exposure and congenitally through the placenta.

There are 3 stages in Chagas disease: the acute one with a local inflammatory lesion that appears at the site where the metacyclic trypomastigotes enter, and the parasite spreads throughout the host organism (Prata 2001, Umezawa et al 2000); the chronic phase in which the diversity and severity of the symptoms range from a mild electrocardiographic alteration to sudden death due to cardiac dysrhythmias, varing in different patients and in different regions (Storino \& Milei 1994). In this disease the heart is the organ most commonly involved and the dysrhythmias, branch blocks and cardiac heart failure are symptoms of the $30 \%$ of patients that develop chagasic cardiomiopathy (Storino \& Milei, 1994; Andrade, 1999). but may evolve into the digestive forms, or both cardiac and digestive forms together. Between the acute and the chronic phases exists a period called the chronic indeterminate stage, which is generally symptomless and may last $10 \pm 20$ years (Macedo 1999; Ribero and Rocha 1998).

Electrocardiographic studies give important information about aspects of cardiac function and are a useful tool for measuring the severity of this and others cardiopathies and also helps in the prognosis. 
During the clinical course of Chagas disease electrocardiographic alterations are usually the first clinical evidence of disease progression, but the onset of this abnormality is rarely detected, since it tends to be asymptomatic at the beginning and heart involvement is usually clinically detected in the chronic phase.

The normality or abnormality of the ECG in a chagasic patient is one of the factors that is used to determine the evolution and risk of the cardiopathy (Cuneo et al 1989).

The first human patient infected with T. cruzi to be identified by Carlos Chagas' died of apparently unrelated causes when she was an adult. She had no cardiac, digestive or other clinical manifestations of the disease, and thus constitutes one of the best examples of the indeterminate stage of this disease. This form is seen in $60-70 \%$ of chronic patients, and $2-5 \%$ of patients in the indeterminate phase convert to a cardiac or digestive form each year, for reasons that are not yet clear (Umezawa et al 2000)

This form was thought to be symptomless, but more sensitive tests have demonstrated that patients in this stage may present significant abnormalities (Ribeiro and Rocha 1998). According to cardiologists, this period is the most important to study because could be key in knowing which patient develops the cardiac form of infection (Elizari 1999).

This variable progression from a clinically silent period to another more severe phase is probably the consequence of many factors. One of these could be parasite strain, as it has been suggested that genetically different stocks may produce different clinical symptoms (Miles et al 1981; Montamat et al 1996).Another possible factors are the health of the host and the possible exposure to re-infections (Prata 2001; Revelli et al 1990; Bustamante et al 2002; 2003; 2004; 2005; 2007).

The cardiac chronic form is the most expressive manifestation of Chagas disease, both because of its frequency and because of its severity. It generally appears between the second and fourth decades of life, 5-15 years after the initial infection. The most common signs and symptoms of chronic Chagas cardiopathy are arrhythmia, cardiac failure, atrioventricular and branch blocks, and thromboembolism (Coura 2007). The chronic chagasic cardiomyopathy is an often fatal outcome of this infection, with a worse prognosis than other cardiomyopathies (Bestetti and Muccillo, 1997; Freitas et al 2005). A diffuse myocarditis, intense myocardial hypertrophy, damage and fibrosis, in the presence of very few circulating $\mathrm{T}$. cruzi forms, are the histopathological hallmarks (Higuchi et al 1987). It is also common to find dilatation of the cavities, with the presence of thrombi, fibrosis, and thinning of the ventricular apices, particularly in the left ventricle (Coura 2007). Serious alterations in the sympathetic and parasympathetic nervous systems have also been described (Sterin-Borda and Borda, 1994).

Different researches demonstrates that Chagas' disease continues to be a major cause of heart failure from Mexico to all South America (Capps and Abad 2004; Rigou et al 2001).

Besides Chagas disease also represents an increasing challenge for clinicians in the United States (Bern et al 2007) and some European countries (Reesink 2005) due to the continuous immigration of people from disease-endemic countries (Polo Romero et al 2011)

The entrance of the parasite in the target cells provokes a focal mononuclear inflammation and the cell lysis (Andrade, 1999; Texeira et al., 2006); these pathological lesions are detected in every chagasic patient, present in the heart of $94.5 \%$ of the deaths, and directly related to the persistence of the parasite and the pathogenesis of the disease (Texeira et al., 2006). 
The development of different diagnostic methods with great capacity to evaluate anatomy and cardiac functions-multi planal echodopplercardiography, scintigraphy and radioisotopic angiography-or to identify in long registers the presence of arrhythmias dynamic electrocardiography can create the impression that conventional electrocardiography (ECG) might be an exam of secondary importance for chagasic patients.

But today the ECG is still of great value due to its simplicity to do it by a medical doctor or a technician, low cost and its high sensitivity in detecting, most of the manifestations of chagasic cardiopathy (Garzon et al 1995). Having in mind the epidemiology and distribution of chagasic or potential chagasic patients the use of a simple technology is absolutely relevant.

It has great epidemiological value and is the method of choice in longitudinal population studies in endemic areas; besides the advantages mentioned, its register does not require great qualification or training of the operator. It is known that in the natural history of Chagas disease, the precocity and prevalence of electrocardiographic alterations are related to the survival curves. For all of these reasons it has great diagnostic value.

\section{Electrocardiogram in the acute phase of Chagas disease}

The acute phase of Chagas' disease is the consequence of a generalized infection by T. cruzi, and is characterized by the finding of the parasite in the peripheral blood. It generally takes a benign course with fever and the symptoms are compatible with other pathologies. The mortality of $5 \%$ and $10 \%$ described in this phase is due to myocarditis or meningoencephallitis, and occurs mainly in the first years of life (Garzon et al 1995).

The myocarditis can show variable severity; it may present only with tachycardia or as cardiac insufficiency and hypotension.

The ECG are normal in 63\% of the acute cases (Porto 1964). Sometimes it can show transitory alterations: the most frequent findings are non-specific and common to any myocarditis such as: sinus tachycardia and primary alteration of the ventricular repolarization, low QRS voltage, left ventricular overload and atrioventricular block of first degree.

If the acute chagasic infection goes on with a severe myocarditis, atrioventricular blocks and bundle-branch block can appear. Electrocardiographic characteristics such as inactive areas, ST segment changes, complex ventricular arrhythmia and atrial fibrillation indicate a worse prognosis. The compromise of the ECG in the acute phase could be indicative of the late prognosis of the disease.

Many authors (Macedo 1999; Rassi et al. 2000; Bustamante et al. 2007; Elizari 1999; Storino and Milei 1994) propose that among patients with a normal ECG in this phase only $30 \%$ will have an altered electrocardiogram in the chronic phases; this is the average of infected people that will develop the cardiopathy ; on the other hand, among those showing some abnormality, $60.9 \%$ will show an altered ECG. After the clinical symptoms disappear in the acute phase the electrocardiographic alterations do the same.

One year later $75 \%$ of the cases show a normal ECG. Some (10\%-20\%) alternate normal tracings and abnormal tracings with intermittent first degree atrioventricular block and alteration of the ventricular repolarization. 


\section{Electrocardiogram in the chronic indeterminate phase of Chagas disease}

A positive serological reactions for T. cruzi, a normal thoracic radiography and a normal electrocardiographic tracing are the elements used for the characterization of the chronic indeterminate form of Chagas' disease. This electrocardiographic normality varies in diverse endemic regions: 83\% in Argentina (Rigou et al 2001) 91.6\% in the Brazilian state of Rio Grande do SuI and 68\% in the state of Goias (Garzon et al 1995). It is more common in the first 20 years after the acute form, with the posterior appearance of some type of electrocardiographic alteration at a frequency of $2 \%$ to $5 \%$ per year.

But the study of this silent and long period of the disease, with more sensitive diagnostic methods, either invasive or non-invasive, demonstrates that most chagasic patients with normal ECG have some type of anatomical or functional alteration.

Between 10 and $20 \%$ of patients in the chronic indeterminate stage present electrocardiographic alterations, almost $40 \%$ of them show abnormal echocardiogram and Doppler studies, such as alterations in ventricular relaxation were found in $27.6 \%$, enlargement of cavities in $31 \%$, both phenomena in $31 \%$ and alteration of the parietal motility in 10.3\%.(Rigau et al 2001).

Carrasco et al. 1982, followed up patients for 12 year showing that $100 \%$ of them survived this time when they belong to the group with normal ECG, or with minor ventriculographic alterations, against only $42 \%$ of the group with abnormal ECG without cardiac insufficiency. Other authors (Garzon et al. 1993) studied 109 seropositives patients with normal ECG , 91\% of them presented normal left ventricular ejection fractions, but $43.1 \%$ showed some abnormalities on the cineangiography of the left ventricle.

Table 1 summarizes the most frequent findings on electrocardiograms from 1010 patients with positive serology, in the chronic indeterminate phase of Chagas disease, and that were analyzed by cineangioventriculography or other clinical and hemodynamiccineangiocardiographic evaluation,

\begin{tabular}{|l|c|c|c|c|}
\hline & $\mathrm{N}^{\mathrm{o}}$ of cases & Age & $\begin{array}{c}\text { minor left ventricle } \\
\text { ejection fraction (\%) }\end{array}$ & $\begin{array}{c}\text { Abnormal left } \\
\text { ventricle(\%) }\end{array}$ \\
\hline Normal ECG & 109 & $\mathbf{3 9 . 3} \mathbf{9 . 1}$ & 8.5 & 43 \\
\hline $\begin{array}{l}\text { Ventricular } \\
\text { extrasystoles }\end{array}$ & 40 & $\mathbf{4 7 . 5 \pm \mathbf { 9 . 9 }}$ & 50 & 20 \\
\hline Right branch block & 39 & $\mathbf{4 6 . 1 \pm \mathbf { 1 3 }}$ & 23.1 & 30.8 \\
\hline $\begin{array}{l}\text { Left anterior } \\
\text { hemiblock }\end{array}$ & 18 & $\mathbf{4 5 . 3 \pm \mathbf { 9 . 8 }}$ & 33.3 & 27.8 \\
\hline Anteroseptal fibrosis & 5 & $\mathbf{5 8 . 5} \pm \mathbf{1 2}$ & 60 & 20 \\
\hline
\end{tabular}

Table 1. Isolated findings on the electrocardiogram of 1010 chagasic patients submitted to cineangioventriculography or other clinical and hemodynamic evaluation (Garzon et al 1995).

According with Manzullo et al. 2001, in endemic areas, the right branch block is a strong indicator for probable Chagas etiology, with a probability of 7 to 1 for this disease. However, among 902 young men they have studied, they detected 19 right branch block from which 13 had not positive Chagas serology, and must be necessarily attributed to other causes (Manzullo et al. 2001). 
It is important to conclude that in chagasic patients that are coursing this long and generally asymptomatic period of the disease a normal ECG does not mean absence of functional or anatomical alterations, but all the authors agree that a normal ECG in chagasic patients, symptomatic or not, even coinciding with anatomical or functional alterations indicates a favorable prognosis with less myocardial dysfunction, than in patients with isolated ECG alterations (Garzon et al.1995; Manzullo and Chuit 1999)

\section{Electrocardiogram in the chronic phase of Chagas disease}

The cardiac chronic form is the most expressive manifestation of Chagas disease, both because of its frequency and because of its severity. It generally appears between the second and fourth decades of life, 5-15 years after the initial infection. The most common signs and symptoms of chronic Chagas cardiopathy are arrhythmia, cardiac failure, atrioventricular and branch blocks, and thromboembolism (Coura, 2007). The chronic chagasic cardiomyopathy is an often fatal outcome of this infection, with a worse prognosis than other cardiomyopathies (Bestetti and Muccillo, 1997; Freitas et al. 2005). A diffuse myocarditis, intense myocardial hypertrophy, damage and fibrosis, in the presence of very few circulating T. cruzi forms, are the histopathological hallmarks (Higuchi et al. 1987). It is also common to find dilatation of the cavities, with the presence of thrombi, fibrosis, and thinning of the ventricular apices, particularly in the left ventricle (Coura, 2007). Serious alterations in the sympathetic and parasympathetic nervous systems have also been described (Sterin-Borda and Borda, 1994; Lo Presti et al 2009).

The prevalence of abnormal ECG is described by some authors (Garzon et al. 1995; Manzullo et al. 1995) as 4.3 times greater in seropositive men than in seronegative men, while seropositive women are 2.6 times greater. This means that an important number of patients do not have ECG alterations in the chronic phase of Chagas disease and these are the patients with low risk of death (Manzullo et al. 1995; Rassi et al. 1995) showing that the electrocardiographical studies done periodically are a good prediction indicator of evolution of the cardiac disease.

Table 2 shows a mean of the findings of different authors as the most frequent electrocardiographic abnormalities found in the chronic phase from different regions (Garzon et al. 1995; Manzullo and Chuit 1999; Prata et al. 1993)

\begin{tabular}{|c|c|}
\hline Ventricular extrasystoles & $40 \%$ \\
\hline Right branch block & $35 \%$ \\
\hline Left anterior hemiblock & $31 \%$ \\
\hline Left branch block & $5 \%$ \\
\hline Alterations of the ST-T segment & $27 \%$ \\
\hline Low voltage of the QRS & $5 \%$ \\
\hline First degree auricular-ventricular block & $3 \%$ \\
\hline Ventricular tachycardia & $8 \%$ \\
\hline Atrial fibrillation & $10 \%$ \\
\hline Anteroseptal fibrosis; & $10 \%$ \\
\hline Presence of inactive electrical area. & $15 \%$ \\
\hline
\end{tabular}

Table 2. Mean of the findings of different authors as the most frequent electrocardiographic abnormalities found in the chronic phase from different regions. 
If the analysis is done over dead people by Chagas disease $100 \%$ of them presented cardiomegaly and abnormal ECG. The most frequent ECG abnormalities are summarized in Table 3 ( Manzullo and Chuit 1999; Garzon et al 1995)

\begin{tabular}{|c|c|}
\hline Right bundle branch block & $96.8 \%$ \\
\hline Repolarization primary alterations & $80 \%$ \\
\hline Areas of inactivation & $72 \%$ \\
\hline Polifocal ventricular arrithmia & $100 \%$ \\
\hline
\end{tabular}

Table 3. Most frequent ECG abnormalities in patients dead by cardiac insufficiency provoked by Chagas disease.

In the study of 5710 patients carried out by Manzullo and Chuit (1999), they also analyzed the ECG alterations in 15 people that died by sudden death with chagasic cardiopathy. Their results showed that only 1 patient presented normal ECG, 1 with indication of pace maker and the last 13 presented associated the following ECG alterations: right bundle branch block, left anterior hemiblock, repolarization primary alterations, ventricular inactivated areas, ventricular arrithmia.

The Argentinean people with an age between 20 and 60 years die 2.6 per/1000 yearly while chagasic people of the same age die 4 per/1000, demonstrating that chagasic patient have 53. \% higher risk of death than the rest of the population.

\section{Experimental model for Chagas disease}

The mice model for Chagas' disease was described by Laguens et al. (1980), from a pathological, immunological and electrocardiographic point of view, demonstrating that they reproduce in a short time the three phases of Chagas disease in a similar manner that in patients. The vantages is that 10 to 30 year are reduced to 365 days; in one year post infection this experimental model reproduces the chronic chagasic cardiopathy allowing studies that produce findings to understand the pathophysiology of the disease and consequently the prevention of it. Mover, electrophysiology of normal mice and infected mice have been profusely reviewed (Berut et al. 1996; Wehrens et al. 2000) and have been largely studied in our lab ( Bustamante et al. 2004; 2005; Lo Presti et al. 2006; 2008; 2009) .

\section{Electrocardiograms in the experimental model}

Electrocardiogram (ECG) tracings can be obtained with a digital electrocardiographic unit or any other electrocardiographic unit, under Ketamine CLH, anaesthesia $(10 \mathrm{mg} / \mathrm{kg})$. Electrocardiographic recording of non infected and infected with T. cruzi mice are obtained under anesthesia. The electrocardiographic tracings can be obtained with 6 standard leads (contact electrode) (dipolar leads DI, DII, DIII and unipolar leads aVR, aVL, aVF), as shows Figure 2 , recording at $50 \mathrm{~mm} / \mathrm{s}$ with amplitude set to give $1 \mathrm{mV} / 10 \mathrm{~mm}$. The electrocardiographic parameters analysed are: cardiac frequency, length of the PR segment and duration of the Q-T interval. Data were then transferred to a computer for further analysis. Wave durations (in sec) can be calculated automatically by the software (CardioCom) after cursor placement or can be read by the operator as usually. 

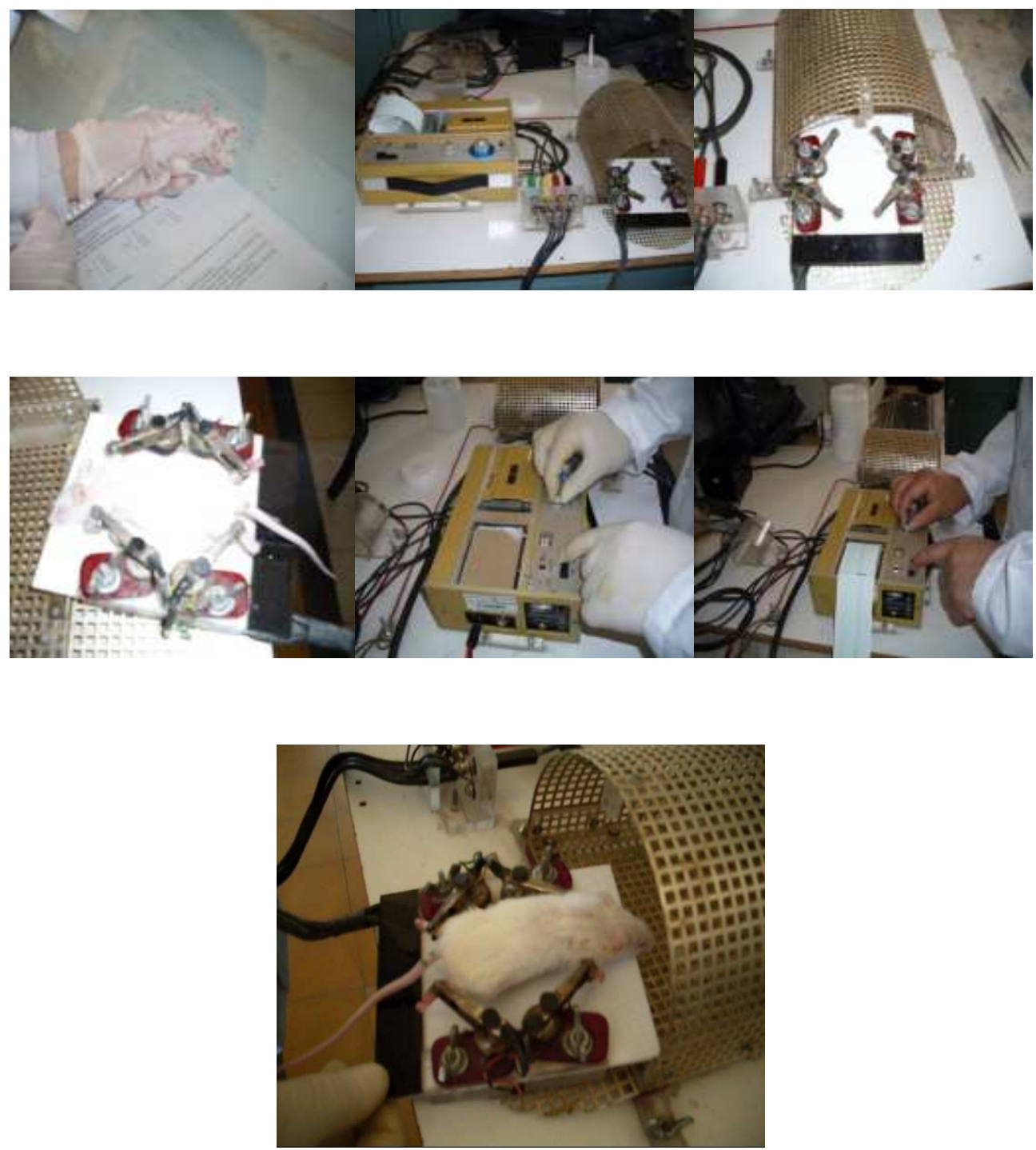

Fig. 2. Mouse placed for the ECG recording under Kethamine CLH anaesthesia The mouse is introduced in a Faraday cage to avoid electrical interferences. 
The main electrocardiographic alterations obtained in this experimental model are summarized in Table 4 and were: modifications in auricle-ventricle conduction (prolonged PQ segment) and in intraventricular conduction (prolonged QRS complex), alteration in auricle-ventricle conduction associated to intraventricular conduction and arrhythmia. Results shown in Table 4 were obtained from several works carried out in our lab (Rivarola et al. 1999; 2001; Bustamante et al. 2002; Rivarola and Paglini-Oliva 2002;Bustamante et al. 2003)

Figure 3 shows the electrocardiographic alterations provoked by the infection of mice with two different T cuzi strain: Tulahuen strain (Taliafero and Pizzi 1955) and with the SGO Z12 isolate (Montamat et al. 1996; Bustamante et al 2003). This isolate was obtained from a chronic patient who lived in an endemic area of Argentina and it was demonstrated, through its electrophoretic pattern (Montamat et al. 1996), that it belongs to zymodeme 12 from Argentina (Bustamante et al 2003 ).

\begin{tabular}{|l|c|c|c|c|c|}
\hline & Uninfected & $\begin{array}{c}\text { Infected } \\
(35 \mathrm{dpi}, \\
\text { acute phase })\end{array}$ & $\begin{array}{c}\text { Infected } \\
(75 \text { dpi,chronic } \\
\text { indeterminate } \\
\text { phase }\end{array}$ & $\begin{array}{c}\text { Infected } \\
(135 \text { dpi,early } \\
\text { chronic phase })\end{array}$ & $\begin{array}{c}\text { Infected } \\
\text { (365 dpi, } \\
\text { late chronic } \\
\text { phase })\end{array}$ \\
\hline $\begin{array}{l}\text { Mean(SE)pulse } \\
\text { rate (beats/m) }\end{array}$ & $446(13.5)$ & $468(12.1)$ & $575(4.8)$ & $526(16.9)$ & $646.19(22.08)$ \\
\hline $\begin{array}{l}\text { Mean(SE)axes } \\
\text { (grades) }\end{array}$ & $66(4.7)$ & $51(4.7)$ & $44(2.3)$ & $55(2.9)$ & $57(3)$ \\
\hline PQ intervals (s) & 0.02 & $0.02-0.04$ & $0.03-0.04$ & $0.02-0.05$ & $0.02-0.05$ \\
\hline QRS intervals (s) & $0.02-0.03$ & $0.02-0.03$ & $0.02-0.04$ & $0.02-0.06$ & $0.02-0.06$ \\
\hline $\begin{array}{l}\% \text { of mice } \\
\text { showing some } \\
\text { ECG abnormalities }\end{array}$ & 2 & 12.5 & 60 & 66 & 60 \\
\hline
\end{tabular}

Dpi : days post infection. Mean (SE)

Table 4. Mean results of the electrocardiographic studies carried out in 100 uninfected mice and in 100 mice during the acute, chronic indeterminate and chronic stage of the T. cruzi infection. 


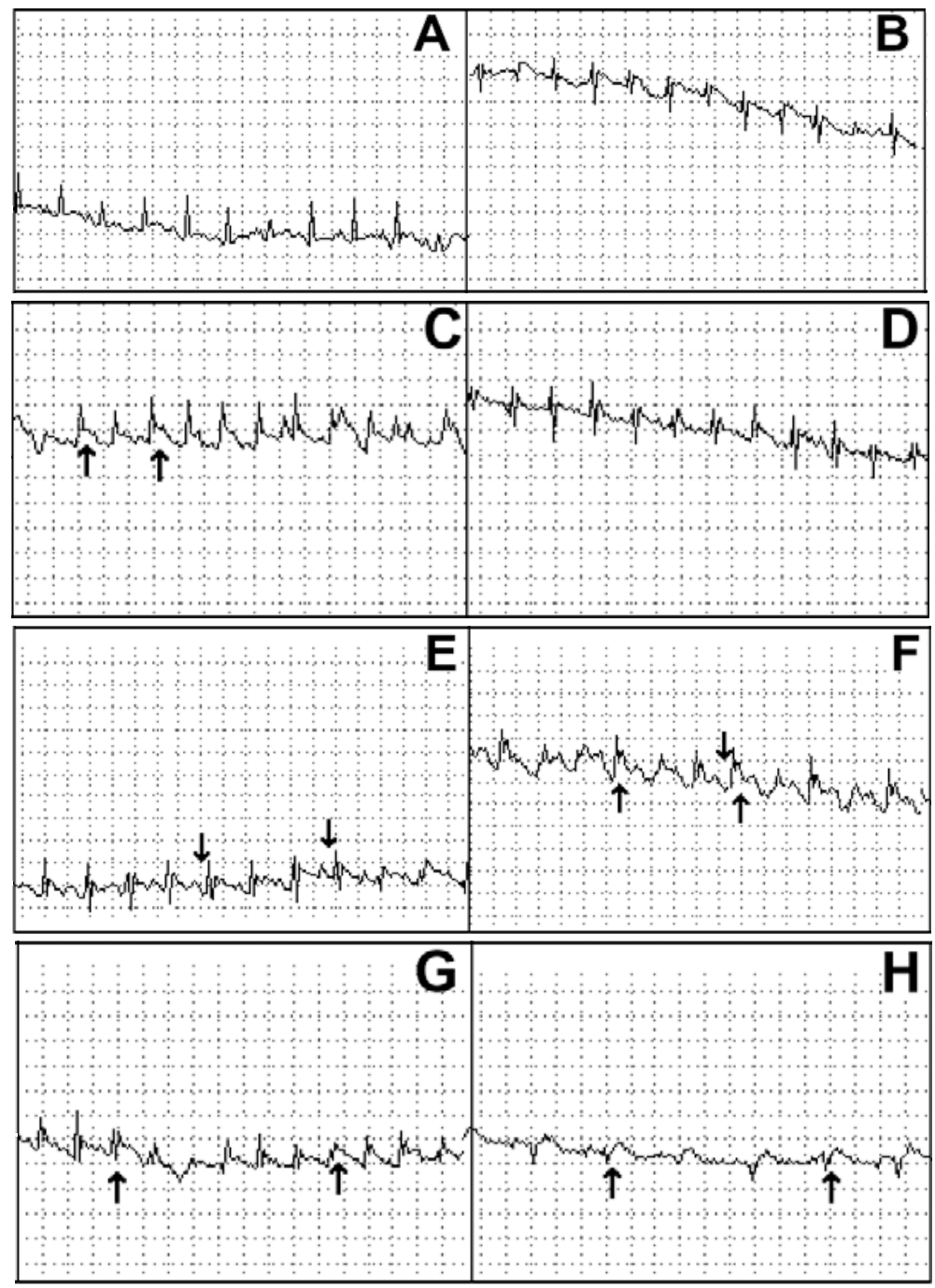

Fig. 3. Electrocardiograms in DIII dipolar lead obtained from: (A) uninfected mice showing no electrocardiographic alterations; (B) Tulahuen strain infected mice 75 days p.i.(postinfection) with no conductive alterations ( $50 \%$ of the mice); (C) Tulahuen strain-infected mice 75 days p.i. showing intra-ventricular blockade (IVB) (arrows) (19\% of the mice from this group); (D) SGO-Z12 isolate-infected mice 90 days p.i. with no electrocardiographic alterations (65\% of the mice); (E) SGO-Z12 isolate-infected mice 90 days p.i. showing auricle-ventricle blockade (AVB) (arrows) (19\% of the mice); (F) SGO-Z12 isolate infected mice 90 days p.i. showing IVB associated with AVB (arrows) (8\% of the mice); (G) Tulahuen strain-infected mice 135 days p.i. (cardiac chronic phase) showing IVB associated with AVB (arrows) (38\% of the mice); (H) SGO-Z12 isolate-infected mice 135 days p.i. (cardiac chronic phase) showing IVB associated with AVB (arrows) (56\% of the mice). 
There is another important aspect to analyze in endemic countries for Chagas disease and is that people living in endemic areas are exposed not only to infections but also to reinfections at any time, therefore we concentrated our efforts on studying this factor as a matter that increases the electrocardiographic abnormalities and the severity of the cardiac damage (Bustamante et al . 2002; 2003; 2004; 2005).

Figure 4 shows the importance of the reinfections to increase the number of ECG abnormalities found in infected mice.

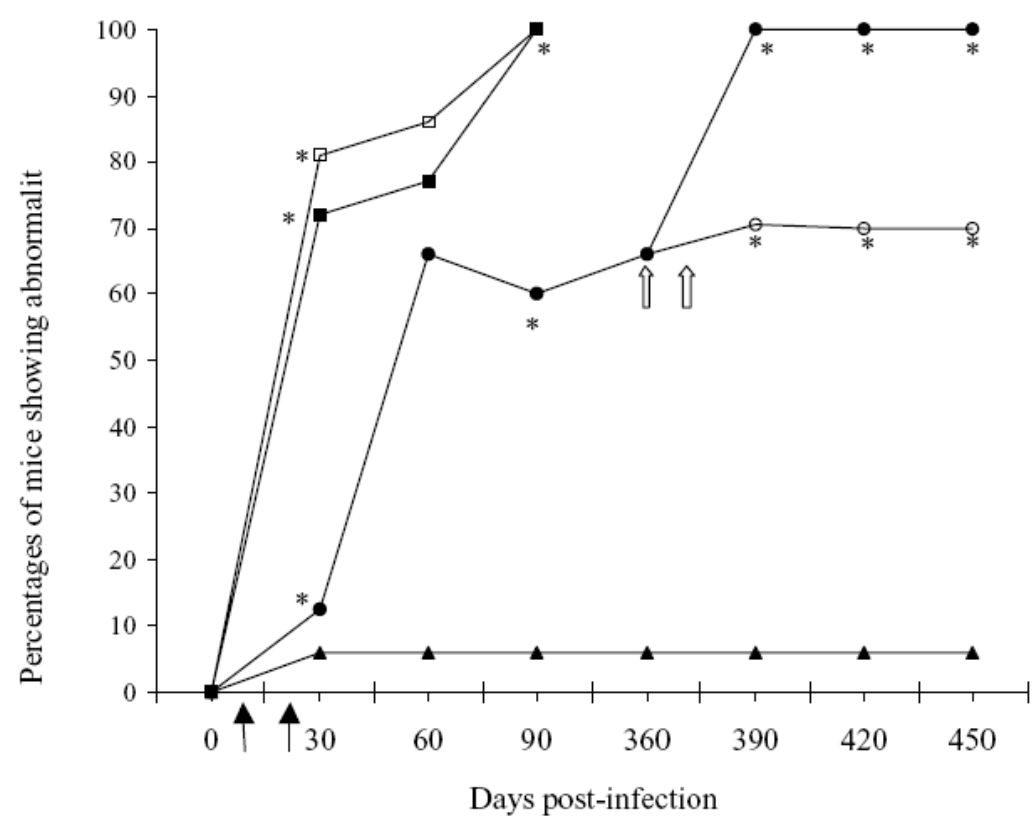

Fig. 4. Evolution of the percentages of non-infected ( $\boldsymbol{\Delta}$, infected without reinfections (०), acutely reinfected with 50 trypomastigotes $(\square)$ or with 500 trypomastigotes $(\mathbf{\square})$ and chronically reinfected $(\bullet)$ mice showing at least 1 kind of electrocardiographic abnormality along the 3 phases of experimental Chagas' disease. Dark arrows indicate acute reinfection time and white arrow indicates chronic reinfection time. ${ }^{*} \mathrm{P}<0.01$ when compared between groups at the same time.

Table 5 shows the most important ECG alterations found in the reinfected models along the evolution of the chagasic infection in a long term study of 450 days post infection (Bustamante et al. 2004). 


\begin{tabular}{|c|c|c|c|c|}
\hline Groups & $\begin{array}{c}\text { Auricle-ventricle } \\
\text { blockade } \\
\text { (prolonged PQ } \\
\text { segment) }\end{array}$ & $\begin{array}{c}\text { IVB: } \\
\text { intraventricular } \\
\text { blockade (prolonged } \\
\text { QRS complex) }\end{array}$ & $\begin{array}{c}\text { Auricle-venticular } \\
\text { blockade associated } \\
\text { with intraventricular }\end{array}$ & Arrhythmias \\
\hline \multicolumn{5}{|l|}{$30 \mathrm{dpi}$} \\
\hline Infected n:32 & 9.4 & 3.1 & NF & NF \\
\hline $\begin{array}{l}\text { Reinfected in the } \\
\text { acute satage n:21 }\end{array}$ & 61.9 & NF & 9.5 & 9.5 \\
\hline $\begin{array}{l}\text { Reinfected in the } \\
\text { chronic stage n:18 }\end{array}$ & 11.1 & 38.9 & 16.5 & 5 \\
\hline Non Infected n:50 & 2 & $\mathrm{NF}$ & NF & 4 \\
\hline \multicolumn{5}{|l|}{$60 \mathrm{dpi}$} \\
\hline Infected n:15 & 46.7 & NF & 20 & $\mathrm{NF}$ \\
\hline $\begin{array}{l}\text { Reinfected in the } \\
\text { acute satage n:14 }\end{array}$ & 50 & 14.3 & 7 & 14.3 \\
\hline $\begin{array}{l}\text { Reinfected in the } \\
\text { chronic stage n:15 }\end{array}$ & 15.4 & 30.8 & 23.1 & 7.7 \\
\hline Non Infected n: 50 & 2 & NF & NF & 4.3 \\
\hline \multicolumn{5}{|l|}{90 dpi } \\
\hline Infected n:15 & 26.7 & 13.3 & $\mathrm{NF}$ & 13.3 \\
\hline $\begin{array}{l}\text { Reinfected in the } \\
\text { acute satage n:9 }\end{array}$ & 67 & NF & 33.3 & NF \\
\hline $\begin{array}{l}\text { Reinfected in the } \\
\text { chronic stage n:9 }\end{array}$ & 71.4 & NF & 28.6 & NF \\
\hline Non Infected n:50 & 2 & NF & NF & 4 \\
\hline \multicolumn{5}{|l|}{$360 \mathrm{dpi}$} \\
\hline Infected n:29 & 48.3 & 3.4 & 6.9 & 6.9 \\
\hline $\begin{array}{l}\text { Reinfected in the } \\
\text { chronic stage n: } 29\end{array}$ & 65 & 5 & 20 & 4 \\
\hline Non Infected n:50 & 2 & $\mathrm{NF}$ & $\mathrm{NF}$ & 10 \\
\hline \multicolumn{5}{|l|}{390 dpi } \\
\hline Infected n:30 & 50 & $\mathrm{NF}$ & 10 & 10 \\
\hline $\begin{array}{l}\text { Reinfected in the } \\
\text { chronic stage n:30 } \\
\end{array}$ & 65 & 5 & 20 & 10 \\
\hline Non Infected n:50 & 2 & $\mathrm{NF}$ & $\mathrm{NF}$ & 4 \\
\hline \multicolumn{5}{|l|}{420 dpi } \\
\hline Infected n:24 & 40 & NF & 15 & 15 \\
\hline $\begin{array}{l}\text { Reinfected in the } \\
\text { chronic stage n:30 }\end{array}$ & 90 & NF & 8 & 5 \\
\hline Non Infected n:50 & 2 & $\mathrm{NF}$ & $\mathrm{NF}$ & 4 \\
\hline \multicolumn{5}{|l|}{450 dpi } \\
\hline Infected n:24 & 50 & NF & NF & 20 \\
\hline $\begin{array}{l}\text { Reinfected in the } \\
\text { chronic stage n: } 24\end{array}$ & 91.6 & NF & 8.4 & NF \\
\hline Non Infected n:50 & 2 & $\mathrm{NF}$ & $\mathrm{NF}$ & 4 \\
\hline
\end{tabular}

NF: not found

Table 5. Percentage of the most frequent ECG alterations in infected and reinfected with T. cuzi mice. 
Results shown in the previous Table demonstrate that when the host is reinfected in the acute phase of experimental Chagas'disease, present significantly more serious electrocardiographic alterations than those developed when the reinfections occur in the chronic stage. Reinfections increased the number of electrocardiographic abnormalities

Thus sudden death described in some chagasic patients, might be related to some of these results.

\section{Final considerations}

Chagas disease affects nearly 16 million people in Latin America and causes 75 to 90 million people to be at risk of infection predominantly in poor regions of Latin America. This disease is also urbanizing and globalizing due to frequent migrations. The electrocardiogram is one of the best and easy way to measure and diagnose Chagas disease. Because of its low cost, easy use and interpretation, it has epidemiological value in endemic areas with difficulties to get access to more sensitive diagnosis methods.

The prevalence of certain alterations such as right bundle branch block associate with left bundle branch and/or ventricular extrasystoles with a positive serological reaction are very simple methods and available any where to make a clear diagnosis of Chagas disease. More sensitive diagnostic methods that allow a better evaluation of the structure and cardiac functions and many different professionals dedicated to the study of Chagas disease from different points of views, have significantly increased the knowledge of this cardiopathy. But the correlation of these findings with characteristics ECG alterations has made this simple method of great valuable to follow patients and make a prognosis of the evolution of the chagasic cardiopathy.

\section{References}

Andrade Z. Immunopathology of Chagas' disease. Mem do Instituto Oswaldo Cruz 94: 7180; 1999.

Bern, C., Montgomery, S.P., Herwaldt, B.L., Rassi Jr., A., Marin-Neto, J.A., Dantas, R.O., Maguirre, J.H., Acquatella, H., Morillo, C., Kirchhoff, L.V., Gilman, R.H., Reyes,

Berul CI, Aronovitz MJ, Wang PJ, Mendelsohn ME. In vivo cardiac electrophysiology studies in mouse. Circulation 94:2641- 2648; 1996.

Bestetti, R. B. and Muccillo, G. Clinical course of Chagas' heart disease: a comparison with dilated cardiomyopathy. Internat J Cardiol 60,: 187-193; 1997.

Biolo A, Ribeiro AL, Clausell N. Chagas cardiomyopathy--where do we stand after a hundred years? Prog Cardiovasc Dis.52:300-316; 2010.

Bustamante JM , Rivarola HW , Fernández AR, Enders JE, Fretes R, Palma JA and PagliniOliva P. Trypanosoma cruzi reinfections in mice determine the severity of cardiac damage.Int J Parasitol 32: 889-896; 2002.

Bustamante JM, Novarese M, Rivarola HW, Lo Presti MS, Fernández AR, Enders JE, Fretes R, Paglini-Oliva PA. Reinfections and Trypanosoma cruzi strains can determine the variability and the prognosis of the chronic Chagas disease. Parasitol Res 100: 1407-1410; 2007. 
Bustamante JM, Rivarola HW, Ferna'ndez AR, et al. Trypanosoma cruzi reinfections provoke synergistic effect and cardiac h-adrenergic receptors' dysfunction in the acute phase of experimental Chagas' disease. Exp Parasitol 103:136- 142; 2003.

Bustamante JM, Rivarola HW, Fretes R, Paglini-Oliva PA. Weekly electrocardiographic pattern in mice infected with two different Trypanosoma cruzi strains .Internat J Cardiol Int J Cardiol. 102:211-217; 2005.

Bustamante JM, Rivarola HW Palma JA, Paglini-Oliva P. Electrocardiographic characterization in Trypanosoma cruzi reinfected mice. Parasitology 128:415-419; 2004.

Capps L and Abad B. Chagas cardiomyopathy and serologic testing in a small rural hospital in Chiapas, Mexico. Pan Am J Public Health 15: 337-340; 2004.

Carrasco H.A.; Barbosa, J.S.; Inglessis, G.; Fuenmayor, A. \& Molina, C. -Left ventricular cineangiography in Chagas' disease: detection of early myocardial damage. Am Heart J 104: 595-602; 1982.

Coura, J. R. . Chagas disease: what is known and what is needed . A background article. Mem do Instituto Oswaldo Cruz 102:113-122; 2007.

Cuneo CA, Molina de Raspi E, Basombrio MA. Prevention of electrocardiographic and histopathological alterations in the murine model of Chagas' disease by preinoculation of an attenuated Trypanosoma cruzi strain. Rev Inst Med Trop Sao Paulo 31: 248- 55; 1989.

Elizari, M.B.. Chagasic myocardiopathy. Historical prospective. Medicina (Buenos Aires) 59: 25-40; 1999.

Freitas, H. F., Chizzola, P. R., Paes, A. T., Lima, A. C. Mansur, A. J. Risk stratification in a Brazilian hospital-based cohort of 1220 outpatients with heart failure : role of Chagas' heart disease. Internat J Cardiol 102: 239-247; 2005.

Garzon SAC, Lorga AM, Nicolau JC. Electrocardiography in Chagas' heart disease. Sao Paulo Med J 113:802-813; 1995.

Higuchi, M. L., De Morais, C. F., Pereira Barreto, A. C., Lopes, E. A., Stolf, N., Bellotti, G. and Pileggi, F. . The role of active myocarditis in the development of heart failure in chronic Chagas' disease: a study based on endomyocardial biopsies. Clin Cardiol 10: 665-670; 1987.

Laguens RP, Cabeza Meckert P, Basombrio M A, Chambó M A, Cossio P, Arana A R. \& Gelpi R J. Infección crónica del ratón con Trypanosoma cruzi. Modelo experimental de enfermedad de Chagas. Medicina 40: 33; 1980.

Lo Presti S, Bustamante JM, Rivarola HW, Fernández AR, Enders J, Fretes R, Levin G, Paglini-Oliva $\mathrm{P}$. Changes in the cardiac $\beta$ adrenergic system provoked by different T. cruzi strains. Internat J Cardiol 111: 104-112; 2006.

Lo Presti S, Bustamante JM, Rivarola HW, Fernández AR, Enders J, Fretes R, Levin G, Paglini-Oliva P. Some components of the cardiac beta adrenergic system are altered in the chronic indeterminate form of the experimental Trypanosoma cruzi infection. I J Parasitol 38:1481-92; 2008. 
Lo Presti S, Rivarola W, Levin G, Cerban F, Fretes R, Paglini-Oliva P. Involvment of the cardiac beta adrenergic system in the chronic phase of Chagas disease. Parasitology. 136: 905-918; 2009.

Lo Presti, Rivarola HW, Fernández AR, Enders JE,Levin G,Fretes R, Cerbán FM, Garrido VV and Paglini-Oliva P Involvement of the b-adrenergic system in the cardiac chronic form of experimental Trypanosoma cruzi infection. Parasitology 136:905-918; 2009.

Macedo, V. Indeterminate form of Chagas disease. Mem. Inst. Oswaldo Cruz. 94: 311-316; 1999.

Manzullo E,Boggero HB; Andrade J, Foglia L, Masaúti A .Electrocardiographic Alterations in Young People Seemingly .www.fac.org.ar/scvc; 2001.

Manzullo EC and Chuit R. Risk of Death Due to Chronic Chagasic Cardiopathy . Mem Inst Oswaldo Cruz 94: 317-320; 1999.

Miles, M. A., Cedillos, R. A., Povoa, M., Souza, A. A., de Prata, A. and Macedo, V. Do radically dissimilar Trypanosoma cruzi strains (zymodemes) causeVenezuelan and Brazilian forms of Chagas' disease? Lancet i:1338-1340; 1981.

Moncayo A, Silveira AC.Current epidemiological trends for Chagas disease in Latin America and future challenges in epidemiology, surveillance and health policy. Mem Inst Oswaldo Cruz. 104 :17-30; 2009.

Montamat EE, De Luca D'Oro GM, Galerano RH, Sosa R, Blanco A. Characterization of Trypanosoma cruzi population by zymodemes: correlation with clinical picture. Am J Trop Med Hyg 55:625-628; 1996.

Montamat, E. E., De Luca D'oro, G. M., Galerano, R. H., Sosa, R. and Blanco, A. Characterization of Trypanosoma cruzi population by zymodemes: correlation with clinical picture. Am. J. Trop. Med. Hyg. 55: 625-628; 1996.

P.A., Salvatella, R., Moore, A.C. Evaluation and treatment of Chagas disease in the United States: a systematic review. JAMA 298: 2171-2181; 2007.

Pereira Silva C, Del Carlo CH, Tavares de Oliveira Jr M, Scipioni A, Strunz Cassaro C, Franchini Ramírez JA, et al. Why do patients with chagasic cardiomyopathy have worse outcomes than those with non chagasic cardiomyopathy? Arq Bras Cardiol 91:358-362; 2009.

Polo-Romero FJ, Beato-Pérez JL, Romero-Portilla C. Chagas: an emergent and unknown disease. Rev Clin Esp.211:165-166; 2011.

Porto,C. 0 eletrocardiograma no progn6stico e evoluaoda Doenca de Chagas. Arq Bras Cardiol 17:3 13-46; 1964.

Prata A. Clinical and epidemiological aspects of Chagas' disease. Lancet, Infect Dis 1:92100; 2001.

Prata SP, da Cunha DF, da Cunha SF, Prata SC, Nogueira N. Prevalence of electrocardiographic abnormalities in 2,000 aged and non-aged chagasic patients. Arq Bras Cardiol. 60:369-372; 1993.

Rassi, A., Jr., Rassi, W. C. and Little, W. C. Chagas heart disease. Clin Cardiol 23: 883-889; 2000.

Rassi, Jr A, Rassi A, Little WC, Xavier SS, Rassi SG, Rassi AG, Rassi GG, Hasslocher-Moreno A, Sousa AS, Sacanavacca M. Development and Validation of a Risk Score for Predicting Death in Chagas' Heart Disease Sao Paulo Med J 113:802-813; 1995. 
Reesink, H.W. European strategies against the parasite transfusion risk. Transf Cliniq et Biol 12: 1-4; 2005.

Revelli, S., Berra, H., Valenti, J. et al. Effect of reinfection on the development of rats infected with Trypanosoma cruzi. Rev. Inst. Med. Trop. Sao Paulo 32: 260-268; 1990.

Ribeiro, A.L., Rocha, M.O., Indeterminate form of Chagas disease:considerations about diagnosis and prognosis. Rev.Soc. Bras. Med.Trop. 31: 301-314; 1998.

Rigou DG, Gullone N, Carnevali L, De Rosa AF. Symptomatic Chagas disease. Electrocardiographic and echocardiographic findings. Medicina (Bs Aires).61 :541544; 2001.

Sterin-Borda, L. J. and Borda, E. S. Participation of autonomic nervous system in the pathogenesis of Chagas' disease. Acta Physiol Pharmacol et Ther Lat 44: 109-123; 1994.

Storino, R. \& Milei, J.Enfermedad de Chagas. Mosby, Doyma Argentina, Buenos Aires.1994.

Strino RA and Milei J. Enfermedad de Chagas. Ed Mosby Doyma Argentina; 1994.

Taliaferro WH, Pizzi T. Connective tissue reactions in normal and immunized mice to a reticulotropic strain of Trypanosoma cruzi. .J Infect Dis 96:199-226: 1955.

Texeira, A.R.L., Nascimento, R.J., Sturm, N.R. Evolution and pathology in Chagas disease. Mem do Instituto Oswaldo Cruz 101: 463-491; $2006 .$.

Umezawa E, Stalf AMS, Corbett CEP, Shikanai-Yasuda MA. Chagas' disease. Lancet 357:797- 799; 2000.

Wehrens XHT, Kirchhoff S, Doevendans PA. Mouse electrocardiography: an interval of thirty years. Cardiovasc Res 45:231-237; 2000.

WHO Report on Chagas Disease. World Health Organization on behalf of the Special Programme for Research and Training in Tropical Diseases. 2007. 


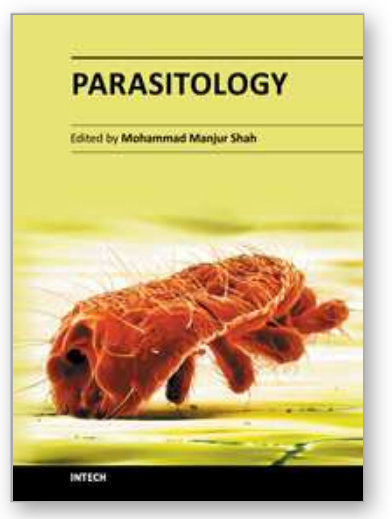

\author{
Parasitology \\ Edited by Dr. Mohammad Manjur Shah
}

ISBN 978-953-51-0149-9

Hard cover, 206 pages

Publisher InTech

Published online 14, March, 2012

Published in print edition March, 2012

Parasitology is an established discipline that covers a wide area of subjects, ranging from the basics (study of life cycle, ecology, epidemiology, taxonomy, biodiversity, etc) to the advanced and applied aspects (human and animal related, although control aspect remains the most important task). There is a great scarcity in the amount of available literature that is freely accessible to anyone interested in the subject. This book was conceptualized with this in mind. The entire book is based on the findings of various studies performed by different authors, comprising reviews and original scientific papers. I hope this book will be helpful to diverse audiences like biologists, zoologists, nematologists, parasitologists, microbiologists, medical doctors, pathologists as well as the molecular biologists, by providing them with a better understanding of the subject.

\title{
How to reference
}

In order to correctly reference this scholarly work, feel free to copy and paste the following:

Patricia Paglini-Oliva, Silvina M. Lo Presti and H. Walter Rivarola (2012). Electrocardiography as a Diagnostic Method for Chagas Disease in Patients and Experimental Models, Parasitology, Dr. Mohammad Manjur Shah (Ed.), ISBN: 978-953-51-0149-9, InTech, Available from:

http://www.intechopen.com/books/parasitology/electrocardiography-as-a-diagnostic-method-for-chagasdisease-in-patients-and-experimental-models

\section{INTECH}

open science | open minds

\author{
InTech Europe \\ University Campus STeP Ri \\ Slavka Krautzeka 83/A \\ 51000 Rijeka, Croatia \\ Phone: +385 (51) 770447 \\ Fax: +385 (51) 686166 \\ www.intechopen.com
}

\author{
InTech China \\ Unit 405, Office Block, Hotel Equatorial Shanghai \\ No.65, Yan An Road (West), Shanghai, 200040, China \\ 中国上海市延安西路65号上海国际贵都大饭店办公楼405单元 \\ Phone: +86-21-62489820 \\ Fax: $+86-21-62489821$
}


(C) 2012 The Author(s). Licensee IntechOpen. This is an open access article distributed under the terms of the Creative Commons Attribution 3.0 License, which permits unrestricted use, distribution, and reproduction in any medium, provided the original work is properly cited. 